\title{
HUMAN SEMINAL TRYPSIN INHIBITORS
}

\author{
J. J. O. SUOMINEN AND M. NIEMI \\ Department of Anatomy, University of Turku, Turku 3, Finland \\ (Received 16th March 1971, accepted 18th August 1971)
}

\begin{abstract}
Summary. The presence of trypsin inhibitors in human seminal plasma was demonstrated, and their effect on the acrosomal trypsin-like enzyme (TLE), as well as on other proteolytic enzymes, was studied. Two inhibitor fractions with approximate molecular weights of 11,500 and 4000 were obtained by gel filtration. The small molecular fraction could only inhibit the activity of trypsin but the larger one completely inhibited the activity of chymotrypsin and partially inhibited that of tissue kallikrein. Neither of the fractions could inhibit the activity of plasmin, thrombin or urokinase. Both inhibitors were heat stable.

The activity of acrosomal TLE was absent in ejaculated intact human and bull spermatozoa, but it could be evoked by repeated washings of the spermatozoa with an electrolyte solution. Both inhibitor fractions inhibited the TLE-activity of intact spermatozoa as well as that of an acrosomal preparation. One of the inhibitors was effective only when dialysed acrosomal preparation or washed spermatozoa in low concentrations were used as the source of the enzyme.
\end{abstract}

\section{INTRODUCTION}

The presence of proteolytic-enzyme inhibitor in human seminal plasma was first demonstrated by Oettlé (1950), who found that the fibrinolytic activity was suppressed by a heat-stable inhibitor. Several investigations have since confirmed the presence in the semen of such inhibitory factor(s) against seminal fibrinolytic activity (von Kaulla \& Shettles, 1953; Rasmussen \& Albrechtsen, 1960; Di Bella, Panazzolo \& Scarpa, 1966). Other proteolytic enzymes have also been shown to be sensitive to inhibitors present in ejaculated seminal fluid or in the secretions of male accessory sex glands (Haendle, Fritz, Trautschold \& Werle, 1965; Fritz, Trautschold, Haendle \& Werle, 1968). Moreover, the presence of a particular trypsin inhibitor could be demonstrated in bull, guinea-pig, hamster, mouse and rat seminal vesicle secretion as well as in the semen of man, boar and bull. Two different types of trypsin inhibitor were purified from the guinea-pig seminal vesicles. One was capable of inhibiting plasmin in addition to trypsin but both were ineffective against chymotrypsin, kallikrein and thrombin (Fritz, Fink, Meister \& Klein, 1970). On the other hand, an inhibitor could be demonstrated in the bull semen, which was able to inhibit not only trypsin and plasmin but also chymotrypsin and kallikrein.

The seminal trypsin inhibitor can affect the acrosomal trypsin-like activity 
of bull (von Waldschmidt, Hoffmann \& Karg, 1966), rabbit (Zaneveld, Srivastava \& Williams, 1969, 1970) and human spermatozoa (Suominen, Multamäki \& Niemi, 1970). The trypsin-like enzyme (TLE) in the acrosome is thought to be necessary for removal of the zona pellucida (Yamane, 1935; Stambaugh \& Buckley, 1968; Multamäki \& Niemi, 1972). The seminal trypsin inhibitor may therefore be an important factor in the capacitation-decapacitation process (Zaneveld et al., 1969). In this study, the nature of the trypsin inhibitor complex in human seminal plasma has been further investigated.

\section{MATERIAL AND METHODS}

\section{Semen}

Human semen samples were obtained from a fertility clinic, rabbit semen was collected by using an artificial vagina and bull semen was kindly supplied by a local breeding unit. Cell-free seminal plasma was produced by centrifugation at $2800 \mathrm{~g}$ for $15 \mathrm{~min}$, and was either used for chemical analyses immediately or frozen and stored at $-25^{\circ} \mathrm{C}$ until required.

The TLE of human and bull spermatozoa was prepared as follows (Hartree $\&$ Srivastava, 1965): the spermatozoa were first separated from the seminal plasma by centrifugation at $900 \mathrm{~g}$ for $15 \mathrm{~min}$. The sedimented spermatozoa were suspended in Krebs-Ringer-fructose solution, the volume of which was adjusted to equal that of the original semen sample and the suspension was then recentrifuged at $900 \mathrm{~g}$ for $15 \mathrm{~min}$. This procedure was repeated five times. Microscopical examination carried out at this stage revealed essentially undamaged spermatozoa with intact acrosomes but lacking cytoplasmic droplets.

The washed spermatozoa were finally suspended in saline solution and the acrosomes were separated from the washed bull spermatozoa by shaking them with glass beads for $30 \mathrm{~min}$. The glass beads were allowed to sediment and the supernatant was centrifuged at $2800 \mathrm{~g}$ for $15 \mathrm{~min}$ to separate the residual spermatozoa. Visual control under the light microscope showed that the great majority of the spermatozoa had lost their acrosomes. The supernatant was then recentrifuged at $70,000 \mathrm{~g}$ for $60 \mathrm{~min}$, and the supernatants were pooled and used as a source for TLE. This source was referred to as the 'acrosomal preparation'. A part of the acrosomal preparation was dialysed for $24 \mathrm{hr}$ against saline solution buffered with tris- $\mathrm{HCl}(5 \mathrm{mmol} / \mathrm{litre}, \mathrm{pH} 7 \cdot 5)$. The whole preparative procedure was carried out at temperatures from 0 to $+4^{\circ} \mathrm{C}$.

\section{Enzyme activities}

Incubations were carried out at $+37^{\circ} \mathrm{C}$ for $60 \mathrm{~min}$, unless otherwise indicated. The incubation mixture consisted of equal volumes $(0.1 \mathrm{ml})$ of buffer, enzyme, inhibitor and substrate solution. Tris- $\mathrm{HCl}$ buffer $(0.1 \mathrm{~mol} / \mathrm{litre})$ was used throughout. The inhibitor was replaced by an equal volume of saline solution in the control incubations. Trypsin (Bovine pancreas, $2 \times$ cryst., Sigma Chem. Co.) and TLE activity was determined using BAPA ( $\mathrm{N}$-benzoylDL-arginine $p$-nitroanilide, Sigma Chem. Co.) as a substrate. Chymotrypsin (Bovine pancreas, $2 \times$ cryst., Sigma Chem. Co.) activity was measured with ATEE (N-acetyl-L-tyrosine ethyl ester, Sigma Chem. Co.), kallikrein activity 
(Padutin ${ }^{\star}$, kallikrein from hog pancreas, Bayer) was determined with BAEE (N-benzoyl-L-arginine ethyl ester, Sigma Chem. Co.), plasmin (Plasmin from human serum, AB Kabi) and thrombin activities (Topostasine ${ }^{\oplus}$, F. HoffmanLaRoche) were demonstrated using TAME (N-tosyl-L-arginine methyl ester, Sigma Chem. Co.) as substrate and for the determination of urokinase (Urokinase reference standard, Leo Pharmac. Products), AGLME (N-acetyl-Llysine methyl ester, Cyclo Chem. Co.) was used as substrate. The enzyme and substrate concentrations and the $\mathrm{pH}$ of the incubation mixtures are included in the results.

The hydrolysis of BAPA was stopped by adding $0.2 \mathrm{ml}$ acetate- $\mathrm{HCl}$ buffer $(0 \cdot 1 \mathrm{~mol} /$ litre, $\mathrm{pH} 4 \cdot 2)$, and the extinction $\left(\mathrm{E}_{383}\right)$ of liberated $p$-nitroaniline was measured. The hydrolysis of ester substrates was measured by determining the amount of unhydrolysed substrate present according to the method of Kabacoff, Umhey, Wohlman \& Avakian (1963), and optical density readings were taken at $540 \mathrm{~nm}$.

\section{Enzyme inhibition}

The inhibitor sample was added to the enzyme-buffer solution, and the mixture was preincubated at $+37^{\circ} \mathrm{C}$ for 15 min before the substrate was added. The inhibitory effect is expressed in terms of Inh. $\mathrm{mU}$, one unit being the amount of the inhibitor, which reduces the substrate hydrolysis by 1 $\mu \mathrm{mol} / \mathrm{min}$.

\section{Protein concentration}

This was measured according to the method described by Lowry, Rosebrough, Farr \& Randall (1951).

\section{Gel filtration}

Sephadex G-75 gel (Pharmacia), particle size 40 to $120 \mu \mathrm{m}$, was used according to the manufacturer's instructions. The gel was packed into a column $(2 \cdot 1 \times 85 \mathrm{~cm})$ and stabilized with normal saline, which was buffered with tris-HCl ( $5 \mathrm{mmol} /$ litre, $\mathrm{pH} 7.5$ at room temperature). The seminal plasma sample $(4.0 \mathrm{ml})$ was applied on the column, and the elution was carried out with the stabilizing buffer. Fractions $(4.0 \mathrm{ml})$ were collected with a flow rate of $0.1 \mathrm{ml} / \mathrm{cm}^{2} / \mathrm{min}$. The trypsin-inhibiting capacity of the fractions was measured, and the active fractions were pooled and concentrated by ultrafiltration.

\section{Utrafiltration}

This was performed with Diaflo-apparatus (Amicon N.V.) and the membrane used was UM-2 (molecular exclusion limit, 1000). The pooled fractions were concentrated to a quarter of the original volume.

\section{RESULTS}

Experiments with seminal plasma

To determine the trypsin inhibitor content in human, rabbit and bovine seminal plasma, the samples were diluted with saline solution to $1: 25,1: 50$ and 
$1: 300$, respectively. The results were expressed as the mean values of five different samples, the following inhibitor concentrations (Inh. $\mathrm{mU} / \mathrm{ml}$ undiluted seminal plasma) being obtained: human 163, rabbit 332 and bull 3380 . Thus, the approximate relative inhibitor concentrations were $1: 2: 20$ for man, rabbit and bull, respectively.

The inhibition of trypsin by human seminal plasma was linear (Text-fig. 1). A weak increase in BAPA hydrolysis by small seminal plasma quantities was noticed, which was probably due to an activation of trypsin by an unknown

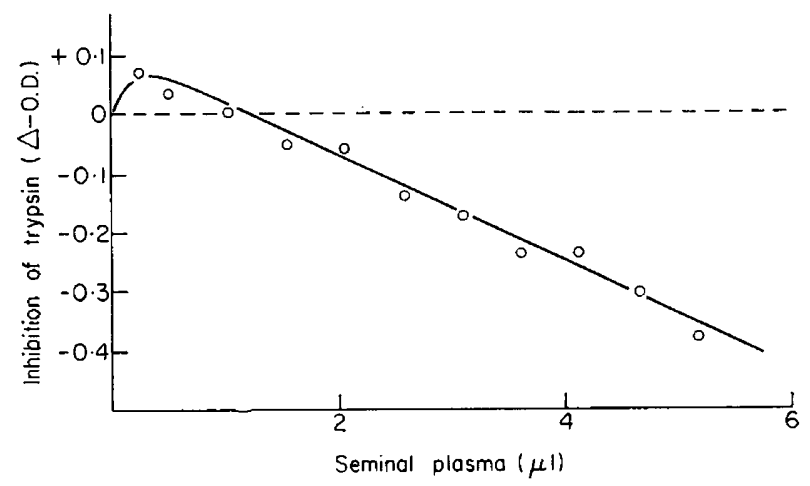

TeXT-FIG. 1. Inhibition of trypsin activity by human seminal plasma. Substrate: BAPA $(0.25 \mathrm{mmol} / \mathrm{l})$, buffer: tris-HCl $(0 \cdot 1 \mathrm{~mol} / \mathrm{l}, \mathrm{pH} 8.0)$, Incubation time: $60 \mathrm{~min}$.

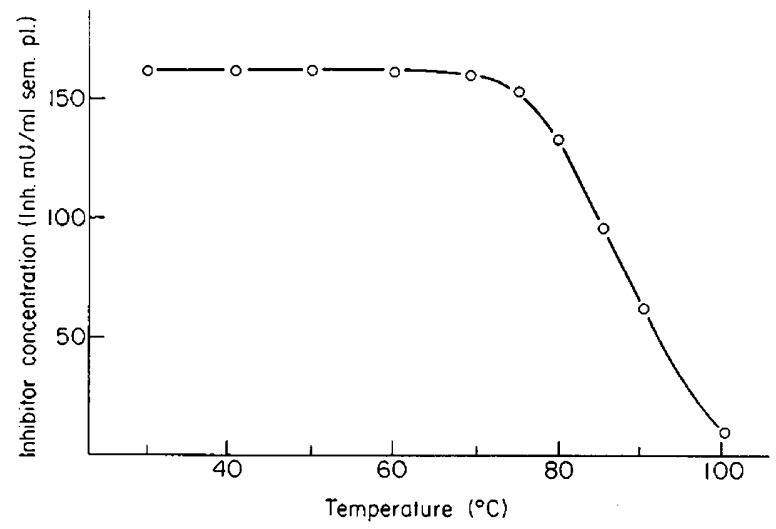

TEXr-FIG. 2. The effect of temperature on the stability of the trypsin-inhibiting capacity in human seminal plasma. Diluted seminal plasma $(1: 25)$ preincubated at various temperatures for $15 \mathrm{~min}$.

factor in the seminal plasma. The heat stability of the trypsin inhibitor in human seminal plasma is shown in Text-fig. 2. A significant inactivation was observed only at temperatures over $+80^{\circ} \mathrm{C}$.

\section{The effect of washings on acrosomal trypsin-like enzyme activity}

No TLE activity could be demonstrated when ejaculated, intact human or bull spermatozoa were used as the source of the enzyme. The TLE could, however, be activated by washing the spermatozoa with an electrolyte solution (Text-fig. 3). 


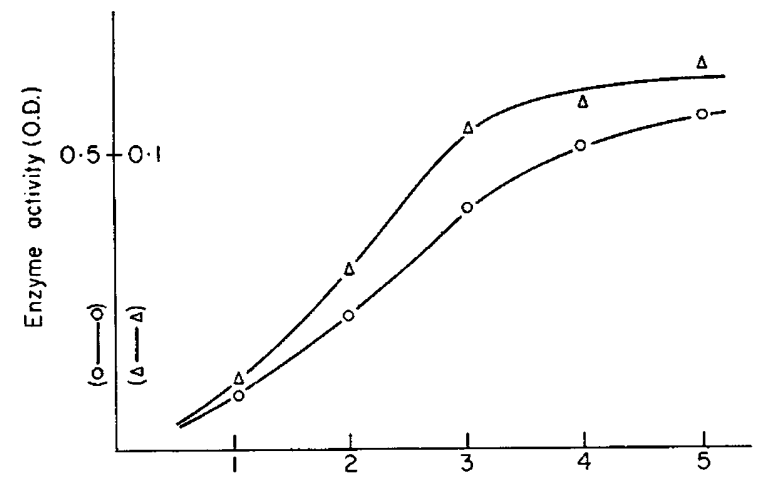

No. of spermatozoal washings

TEXT-FIG. 3. The effect of repeated sperm washings on the TLE-activity in intact spermatozoa. Human spermatozoa $(\Delta)$ were used in a concentration of $35 \times 10^{6} / \mathrm{ml}$ and those of bull $(O)$ in $250 \times 10^{6} / \mathrm{ml}$. Incubation time: $60 \mathrm{~min}$.

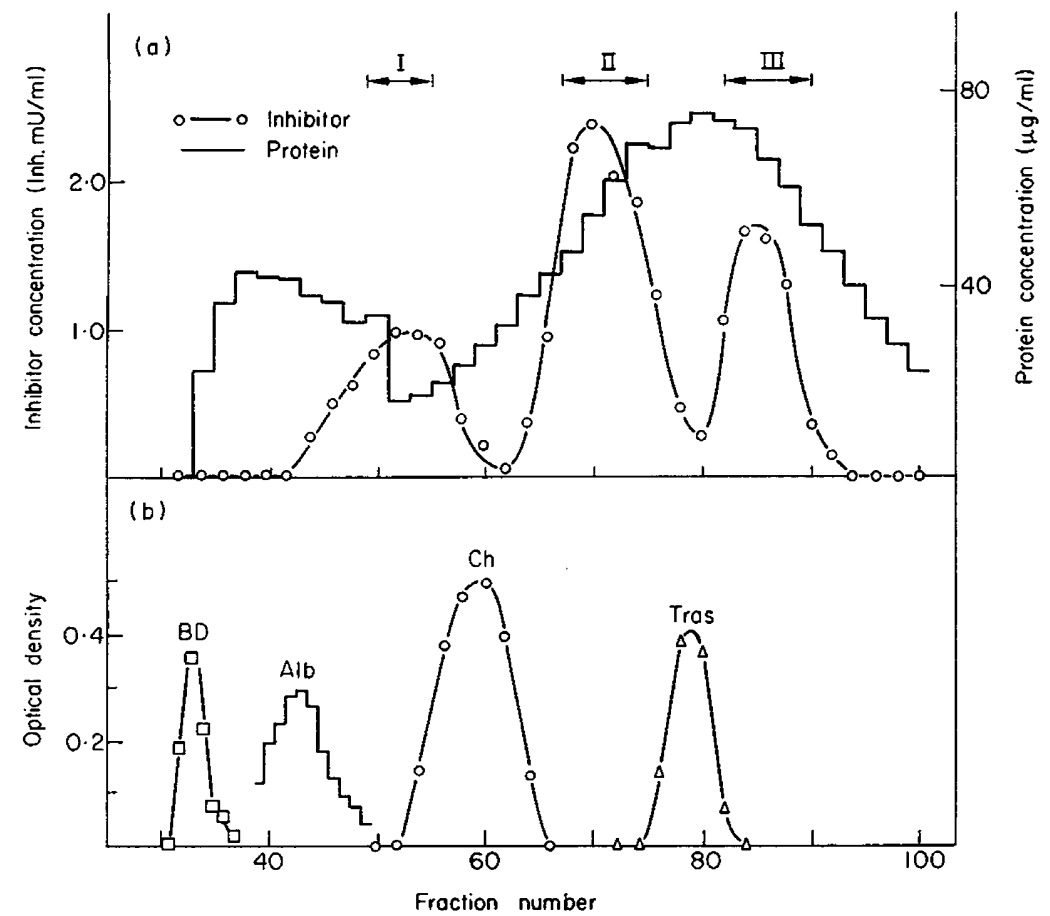

TEXT-RIG. 4. The distribution of the trypsin inhibitors and proteins in human seminal plasma after Sephadex G-75 gel filtration (a). The fractions were pooled as follows: $I=49$ to $55, I I=67$ to $75, I I I=82$ to 90 . The distribution of some reference substances under identical conditions are given in (b). Abbreviations: $\mathrm{Alb}=$ bovine albumin, $\mathrm{BD}=$ blue dextran (Pharmacia), $\mathrm{Ch}=$ bovine chymotrypsin (Sigma Chem. Co.) and Tras $=$ Trasylol $^{\circ}$.

Fractionation of the trypsin inhibitors in human semen

A typical distribution of trypsin inhibitors and proteins in Sephadex G-75 gel filtration is presented in Text-fig. 4 ( $a$ and $b$ ) and indicates the distribution of some reference proteins under identical conditions. Three different areas with trypsin inhibitor capacity were obtained in every experiment, and the tubes 
with fractions containing inhibitors were pooled as follows: Tubes 49 to 55, 67 to 75 and 82 to 90 . The three preparations were labelled I to III, respectively. The relative trypsin inhibitor content of the preparations varied, however, according to the ionic strength used for the elution. When $\mathrm{NaCl}$ was omitted and the elution was carried out with pure tris-HCl buffer, most of the inhibitor was eluted into the first preparation, only traces being present in preparations II and III.

\section{Characterization of the inhibitor preparations}

The molecular weight of the three inhibitor preparations calculated according to Whitaker (1963) were $\mathrm{I}=34,000, \mathrm{II}=11,500$ and $\mathrm{III}=4000$. When the inhibitor preparations were incubated at various temperatures (Text-fig. 5), II and III were stable at all tested temperatures and even a weak increase of the inhibitory capacity was observed after treatment at higher temperatures. By contrast, preparation I was inactivated almost completely at temperatures over $+50^{\circ} \mathrm{C}$.

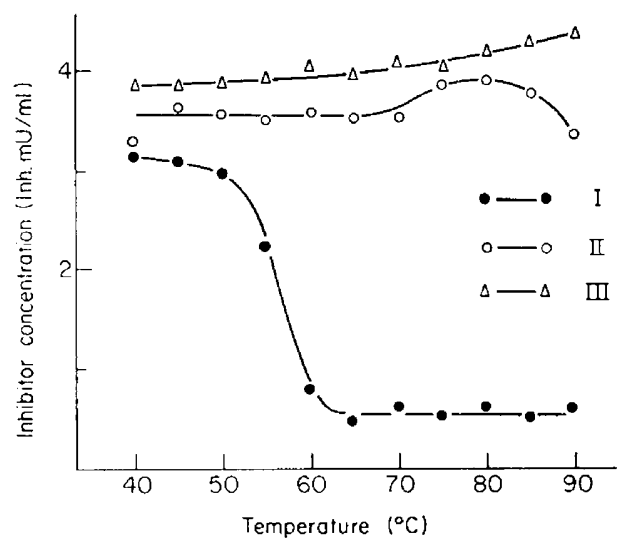

TEXT-FIG. 5. The effect of temperature on the stability of the trypsin inhibitor fractions in human seminal plasma (for the collection of the fractions see Text-fig. 4). The fractions were preincubated at various temperatures for $15 \mathrm{~min}$.

Before the effect of the inhibitors on proteolytic enzymes was tested, preparations I and II were incubated at $+65^{\circ} \mathrm{G}$ for $45 \mathrm{~min}$ to destroy any enzyme contamination from the seminal plasma. The results of the inhibition experiments are presented in Table 1 . Trasylol (Bayer) was used as a reference inhibitor in concentration of $10 \mu \mathrm{mol} /$ litre. The effect of Trasylol on the proteolytic enzymes was the same as that reported in the literature (Wu \& Laskowski, 1955; Walton, 1967). Trypsin was inhibited by all three preparations, but preparation II could also completely inhibit the activity of chymotrypsin and, to a lesser extent, that of kallikrein. The inhibiting effect of preparation I on the activity of kallikrein was equal to that of preparation II. None of the human seminal inhibitors could inhibit plasmin, thrombin or urokinase. The inhibitory effect of preparations II and III was tested on the TLE-activity of intact bull spermatozoa and of the acrosomal preparation (Table 2). Preparation III effectively inhibited TLE-activity both in the intact spermatozoa and 
TABLE 1

INHIBITION OF SOME PROTEOLYTIC ENZYMES BY THREE INHIBITOR FRACTIONS OBTAINED BY GEL FILTRATION OF HUMAN SEMINAL PLASMA AND BY TRASYLOL ${ }^{\circledR}$

\begin{tabular}{|c|c|c|c|c|c|c|c|c|}
\hline \multirow{2}{*}{ Enzyme } & \multirow{2}{*}{$\begin{array}{l}\text { Amount of } \\
\text { the enzyme }\end{array}$} & \multirow{2}{*}{ Substrate } & \multirow{2}{*}{$\begin{array}{l}\text { Substrate } \\
\text { concentration } \\
(\text { mmol/l })\end{array}$} & \multirow{2}{*}{$\underset{\text { incubation }}{p H}$ of } & \multicolumn{3}{|c|}{$\begin{array}{l}\text { Inhibitor } \\
\text { fraction }\end{array}$} & \multirow{2}{*}{ Trasylol } \\
\hline & & & & & $I$ & $I I$ & $I I I$ & \\
\hline $\begin{array}{l}\text { Trypsin } \\
\text { Chymotrypsin } \\
\text { Kallikrein } \\
\text { Plasmin } \\
\text { Thrombin } \\
\text { Urokinase }\end{array}$ & $\begin{array}{l}2.0 \mu \mathrm{g} \\
0.33 \mu \mathrm{g} \\
0.05 \mathrm{BU} \\
0.1 \mathrm{mg} \\
1.0 \mathrm{NIH}-\mathrm{U} \\
25 \text { Ploug-U }\end{array}$ & $\begin{array}{l}\text { BAPA } \\
\text { ATEE } \\
\text { BAEE } \\
\text { TAME } \\
\text { TAME } \\
\text { AGLME }\end{array}$ & $\begin{array}{l}0 \cdot 25 \\
5 \cdot 0 \\
5 \cdot 0 \\
5 \cdot 0 \\
5 \cdot 0 \\
5 \cdot 0\end{array}$ & $\begin{array}{l}8 \cdot 0 \\
7 \cdot 5 \\
8 \cdot 5 \\
8 \cdot 0 \\
8 \cdot 0 \\
8 \cdot 0\end{array}$ & $\begin{array}{r}31 \\
0 \\
27 \\
0 \\
0 \\
0\end{array}$ & $\begin{array}{r}75 \\
100 \\
31 \\
0 \\
0 \\
0\end{array}$ & $\begin{array}{r}68 \\
0 \\
1 \\
0 \\
0 \\
1\end{array}$ & $\begin{array}{r}100 \\
99 \\
99 \\
100 \\
5 \\
4\end{array}$ \\
\hline
\end{tabular}

The extent of inhibition is given as a percentage of the uninhibited value. Incubation time: $60 \mathrm{~min}$. Abbreviations: $\mathrm{BU}=$ biological unit, $\mathrm{U}=$ unit; for others, see the text.

TABLE 2

THE EFFEGT OF TWO HUMAN SEMINAL TRYPSIN INHIBITORS AND TRASYLOL ON THE BAPA-HYDROLYSIS BY INTACT BULL SPERMATOZOA AND IN AN ACROSOMAL PREPARATION

\begin{tabular}{l|c|cc|c}
\hline \multirow{2}{*}{ Enzyme } & \multirow{2}{*}{$\begin{array}{l}\text { Incubation } \\
\text { time (min) }\end{array}$} & \multicolumn{2}{|c|}{ Inhibitor fraction } & \multirow{2}{*}{ Trasylol } \\
\cline { 3 - 4 } & & $I I$ & III & \\
\hline Intact spermatozoa $\left(250 \times 10^{6} / \mathrm{ml}\right)$ & 15 & 0 & 31 & 97 \\
Intact spermatozoa $\left(50 \times 10^{6} / \mathrm{ml}\right)$ & 60 & 29 & 82 & 99 \\
Acrosomal homogenate & 60 & 4 & 48 & 86 \\
Acrosomal homogenate, dialysed & 60 & 29 & 73 & 96 \\
\hline
\end{tabular}

The extent of inhibition is given as a percentage from the uninhibited value.

in the acrosomal preparation. Preparation II was more potent against pancreatic trypsin, and was able to inhibit the TLE-activity only when dialysed acrosomal preparation or spermatozoa in low concentrations were used as the source of the enzyme.

\section{DISCUSSION}

The results confirm the earlier report by Haendle et al. (1965) of the presence in high concentration of a trypsin inhibitor in human and bovine seminal plasma. The method used for the separation of seminal plasma and spermatozoa produced preparations free from cytoplasmic-droplets, as had been reported by Dott \& Dingle (1968). We have also been able to demonstrate the presence of trypsin inhibitor in rabbit seminal plasma, where its concentration is approximately double that in human seminal plasma.

The trypsin inhibitor in human seminal plasma could be separated into three different portions by gel filtration. The first of these had the highest molecular weight and apparently represents a complex formation of the other two. This assumption was supported by the fact that the yield of the first portion was 
lowest when isotonic $\mathrm{NaCl}$ was used in the elution buffer but when $\mathrm{NaCl}$ was omitted, the first portion was dominant.

The inactivation of inhibitor preparation $\mathrm{I}$ at temperatures over $+50^{\circ} \mathrm{C}$ suggests that the structure of the seminal inhibitors may be altered when their carrier proteins are denatured. This could explain the incompetence of preparation I to inhibit chymotrypsin, although preparation II was not affected. It may be of some significance that, while preparations II and III were equally effective in inhibiting pancreatic trypsin, they clearly differed in their ability to inhibit acrosomal TLE. This may indicate a true difference between trypsin and the acrosomal enzyme or a different binding mechanism between the inhibitors and these enzymes.

The human seminal trypsin inhibitors are similar to those of bull semen (Haendle et al., 1965; Fritz et al., 1968) except in their inability to inhibit plasmin. This may be a true difference or it may merely be due to a difference in the substrates for plasmin assays. Recently, Fritz et al. (1970) have isolated several trypsin- and trypsin-plasmin inhibitors from the seminal vesicles of the guinea-pig. They differ, however, considerably from those described in the present paper in that the guinea-pig inhibitors don't affect chymotrypsin, but several inhibit plasmin.

Estimation of the molecular weight of small protein molecules by the gel filtration method is rather inaccurate. However, the human seminal trypsin inhibitors differed so clearly from Trasylol ${ }^{\circledR}$ in gel filtration that their moleccular weights were presumed to be quite different. The molecular weight of Trasylol, on the other hand, is reported to be equal or almost equal to that of the inhibitors in bull semen (Fritz et al., 1968). The inhibitory effect of the preparation III cannot depend on the presence of salts, amino acids or other low molecular weight substances, because preparation III could be concentrated by membrane ultrafiltration without any distinct loss of inhibitor capacity.

The ability of bull, rabbit and human seminal plasma to inhibit acrosomal TLE-activity has been reported earlier (von Waldschmidt et al., 1966; Zaneveld et al., 1969; Zaneveld, Srivastava \& Williams, 1970; Suominen et al., 1970). In the present study, both human and bull acrosomal TLE-activity could be evoked by repeated washings of the ejaculated spermatozoa with an electrolyte solution. This could have been due to removal of the inhibitor(s) from acrosomal TLE or could be due to a change in the permeability of the outer acrosomal or plasma membrane for the substrate. Both of the inhibitor preparations were able to inhibit the TLE-activity in intact spermatozoa as well as in the acrosomal preparation. Preparation II, however, was able to inhibit TLE only when dialysed acrosomal preparation or spermatozoa in low concentrations were used as the enzyme source. It is probable, therefore, that the acrosomal TLE can be activated in intact spermatozoa by removing the inhibitor(s) which seem to be rather firmly attached to the spermatozoa (acrosomes).

The attachment of enzyme inhibitors to spermatozoa may be connected with the capacitation phenomenon (Austin, 1951; Chang, 1951, 1957) which may involve a dissociation of enzyme-inhibitor-complexes between acrosomal hydrolases and seminal inhibitors. The successful capacitation of spermatozoa in 'unphysiological' conditions (Barros, 1968; Abney \& Williams, 1969; 
Yanagimachi, 1969) could be explained on this hypothesis, and also the remedial effect on capacitation of some odd treatments, e.g. the effect of oestrogens which may undergo $\mathrm{pH}$-changes in the female reproductive tract and these, in turn, could affect the enzyme-inhibitor-complex. Recently, Stambaugh, Brackett \& Mastroianni (1969) and Zaneveld, Robertson, Kessler, Srivastava \& Williams (1970) demonstrated that fertilization in vitro and in vivo, respectively, can be inhibited by trypsin inhibitors.

\section{AGKNOWLEDGMENT}

This work was supported financially by the Population Council, New York.

\section{REFERENGES}

Abney, T. O. \& Williams, W. L. (1969) Capacitation of sperm in utero inside a cell filter. Fedn Proc. Fedn Am. Socs exp. Biol. 28, 705.

Austis, C. R. (1951) Observations on the penetration of the sperm into the mammalian egg. Aust. $\mathcal{F}$. sci. Res. B, 4, 581 .

BarRos, G. (1968) In vitro capacitation in golden hamster spermatozoa. Anat. Rec. 160, 310.

Chang, M. C. (1951) Fertilizing capacity of spermatozoa deposited into the Fallopian tubes. Nature, Lond. 168, 697.

Chang, M. C. (1957) A detrimental effect of seminal plasma on the fertilizing capacity of sperm. Nature, Lond. 179, 258.

Di Bella, S., Panazzolo, A. \& Scarpa, F. (1966) Sull 'attivita' fibrinolitica del liquido seminale umano. Boll. Soc. ital. Biol. sper. 42, 1797.

DotT, H. M. \& Dingle, J. T. (1968) Distribution of lysosomal enzymes in the spermatozoa and cytoplasmic droplets of bull and ram. Expl Cell Res. 52, 523.

Fritz, H., Fink, E., MeIster, R. \& KLEIN, G. (1970) Isolierung von Trypsininhibitoren und TrypsinPlasmin-Inhibitoren aus den Samenblasen von Meer-schweinchen. Hoppe-Seyler's Z. physiol. Chem. 351, 1344.

Fritz, H., Trautschold, I., Haendle, H. \& Werle, E. (1968) Chemistry and biochemistry of proteinase inhibitors from mammalian tissues. Ann. N.Y. Acad. Sci. 146, 400.

Haendle, H., Fritz, H., Trautschold, I. \& Werle, E. (1965) Über einen hormonabhängigen Inhibitor für proteolytische Enzyme in männlichen accessorischen Geschlechtsdrüsen und im Sperma. Hoppe-Seyler's Z. physiol. Chem. 343, 185.

Hartree, E. F. \& Srivastava, P. N. (1965) Chemical composition of the acrosomes of ram spermatozoa. F. Reprod. Fert. 9, 47.

Kabacofr, B. L., Umhey, M., Wohlman, A. \& Avakian, S. (1963) Sensitive and reproducible assay method for chymotrypsin. F. pharm. Sci. 52, 1188.

Lowry, O. H., Rosebrough, N. J., FarR, A. L. \& Randall, R. J. (1951) Protein measurement with the Folin phenol reagent. F. biol. Chem. 193, 265.

Multamäki, S. \& Niemi, M. (1972) Trypsin-like proteolytic activity in an acrosomal preparation of bull spermatozoa. Int. F. Fert. (in press).

Oetrté, A. G. (1950) Fibrinolytic factors in human semen. Proc. Soc. Study Fert. 2, 71.

Rasmussen, J. \& Albrechtsen, O. K. (1960) Fibrinolytic activity in human seminal plasma. Fert. Steril. 11, 264.

Stambaugh, R., Brackett, B. G. \& Mastrotann, L. (1969) Inhibition of in vitro fertilization of rabbit ova by trypsin inhibitors. Biol. Reprod. 1, 223.

Stambaugh, R. \& Buckiey, Y. (1968) Zona pellucida dissolution enzymes of the rabbit sperm head. Science, N.Y. 161, 585.

Suominen, J. J. O., MultamäKr, S. J. \& NiEmi, M. (1970) Trypsin inhibitor in seminal plasma-a new decapacitation factor? Proc. 11 th Meet. Nordic Fertility Club. Helsinki, 1970.

von Kaulla, K. N. \& Shetrles, L. B. (1953) Relationship between human seminal fluid and the fibrinolytic system. Proc. Soc. exp. Biol. Med. 83, 692.

von Waldschmidt, M., HofrmanN, B. \& Karg, H. (1966) Untersuchungen über die tryptische Enzymaktivität in Gesclechtssekreten von Bullen. Zuchthyg. FortpfiStör. Besam. Haustiere, 1, 15.

Walton, P. L. (1967) The hydrolysis of $\alpha$-N-acetylglycyl-L-lysine methyl ester. Biochim. biophys. Acta, 132, 104 . 
Whitaker, J. (1963) Determination of molecular weights of proteins by gel filtration on Sephadex. Analyt. Chem. 35, 1950.

Wu, F. G. \& LASKowskI, M. (1955) Action of the naturally occurring trypsin inhibitors against chymotrypsin $\alpha$ and $\beta$. F. biol. Chem. 213, 609.

YAMANE, Y. (1935) Kausel-Analytischen Studien über die Befruchtung des Kanincheneies. I. Die Dispersion des Follikelzellen und die Ablosung der Zellen der Corona Radiata des Eies durch Spermatozoen. Cytologia, 6, 128.

YANAGIMACHI, R. (1969) In vitro capacitation of hamster spermatozoa by follicular fluid. F. Reprod. Fert. $18,275$.

Zaneveld, L. J. D., Robertson, R. T., Kessler, M., Srivastaya, P. N. \& Williams, W. L. (1970) Inhibition of fertilization in vivo by mammalian trypsin inhibitors. Fedn Proc. Fedn Am. Socs exp. Biol. 29, 2243.

Zaneveld, L. J. D., Srivastava, P. N. \& Williams, W. L. (1969) Relationship of a trypsin-like enzyme in rabbit spermatozoa to capacitation. F. Reprod. Fert. 20, 337.

Zaneveld, L. J. D., Srivastava, P. N. \& Williams, W. L. (1970) Inhibition by seminal plasma of acrosomal enzymes in intact sperm. Proc. Soc. exp. Biol. Med. 133, 1172. 